Bilek M., Stawarczyk K., Gostkowski M., Olszewski M., Kędziora K.M., Cieślik E. 2016. Mineral content of tree sap from the Subcarpathian region. J. Elem., 21(3): 669-679. DOI: 10.5601/jelem.2015.20.4.932

\title{
MINERAL CONTENT OF TREE SAP FROM THE SUBCARPATHIAN REGION
}

\author{
Maciej Bilek ${ }^{1}$, Kinga Stawarczyk ${ }^{2}$, Michał Gostkowski ${ }^{3}$, \\ Marcin Olszewski ${ }^{4}$, Katarzyna M. Kędziora ${ }^{5}$, Ewa Cieślik ${ }^{6}$
}

\author{
${ }^{1}$ Department of Food and Agriculture Production Engineering \\ ${ }^{2}$ Department of Botany, Institute of Applied Biotechnology and Basic Science \\ University of Rzeszów \\ ${ }^{3}$ Department of Econometrics and Statistics \\ Warsaw University of Life Sciences \\ ${ }^{4}$ Department of Molecular Biotechnology and Microbiology \\ Gdańsk University of Technology \\ ${ }^{5}$ Division of Cell Biology \\ The Netherlands Cancer Institute \\ ${ }^{6}$ Department of Nutrition Technology and Consumption \\ Malopolska Centre of Food Monitoring \\ University of Agriculture in Kraków
}

\begin{abstract}
Tree sap has been used for centuries not only as a source of nutrients available in early spring but also as medicinal substance in folk medicine. Traditionally, it was used to treat various conditions, mostly anaemia and chronic fatigue. This study has been designed to establish the content of metallic elements (sodium, potassium, calcium, magnesium, zinc and copper) in sap collected from eight different species (silver birch, downy birch, hornbeam, Norway maple, boxelder maple, black walnut, black alder and white willow) and to identify which sap has mineral content which would be most beneficial for human health. We measured concentrations of calcium, magnesium, sodium, potassium and zinc on an atomic absorption spectrometer equipped with single-element, hollow cathode lamps and an air/acetylene burner. The content of copper was determined using an atomic absorption spectrometer with Zeeman correction equipped with an electrothermal atomizer and argon as inert gas. White willow sap was determined to have the highest concentrations of magnesium, zinc, calcium and potassium. Moreover, this sap contained the lowest concentration of sodium among all the tree species. The sap with the lowest detected concentration of the metallic elements originated from black alder and boxelder. In conclusion, tree sap can be a valuable source of metallic elements, namely copper, zinc and magnesium, in human diet. Tree sap tapped from white willow is the most valuable in terms of its mineral content. Moreover, the most popular sap of sliver birch has proven to be a rich source of magnesium and zinc.
\end{abstract}

Keywords: tree sap, minerals, intraspecies variability, interspecies variability, nutrition standards.

Maciej Bilek, PhD, Department of Food and Agriculture Production Engineering, University of Rzeszów, Zelwerowicza 4 street, 35-601 Rzeszów, Poland, e-mail: mbilek@univ.rzeszow.pl 


\section{INTRODUCTION}

Tree sap has been used for centuries in traditional medicine to treat diverse conditions such as anaemia, general fatigue, especially in early spring, or skin lesions (Zyryanova et al. 2010, Svanberg et al. 2012, PAPP et al. 2014). The fact that several minerals, important for human health, such as magnesium, zinc and copper are found in tree sap justifies its medicinal use. Interestingly, the presence of bioavailable minerals in birch sap was appreciated as early as in the 1930s. Until now, the mineral content of sap has been described for several species of the genera Betula and Acer, namely silver birch - Betula pendula (VišKelis, Rubinskienè 2011, KüKA et al. 2013), Japanese white birch - Betula platyphylla (JEONG et al. 2012), painted maple - Acer mono (Chung et al. 1995, Moon et al. 2004, Jeong et al. 2011), Norway maple - Acera platanoides (KüKa et al. 2013) and Korean maple - Acer pseudosieboldianum (Chung et al. 1995). Moreover, it has been shown that tracing changes in the content of tree saps may be of benefit to general environmental monitoring (HAJRu, HuldÉn 1990, GREenough et al. 2010). Furthermore, it has been observed that the mineral content of sap determines the quality of syrups produced from it (Morselli et al. 1985, Morselli, Whalen 1987).

Out intention has been to describe the mineral content of sap from eight different tree species. Six of the above species have never been evaluated in this regard before. Another aim of this study has been to identify a species provides sap that is most beneficial for human health. For this purpose, sap samples were collected from trees growing close to one another, which meant to eliminate the growth conditions as a source of variability.

\section{MATERIAL AND METHODS}

Samples of sap were collected from five individual trees belonging to each of the species: silver birch (Betula pendula Roth.), downy birch (Betula pubescens Ehrh.), hornbeam (Carpinus betulus L.), Norway maple (Acer platanoides L.), boxelder (Acer negundo L.), black walnut (Juglans nigra L.), black alder (Alnus glutinosa Gaertn.) and white willow (Salix alba L.). All sampled trees grew on the ground owned by the Institute of Applied Biotechnology and Basic Sciences of the University of Rzeszow (Werynia, Podkarpackie Province, $50.2500^{\circ} \mathrm{N}, 21.8333^{\circ} \mathrm{E}$ ) - Figure 1.

Samples were collected between 26 of February and 16 of March 2014. They were obtained in an area that is not submitted to any agricultural activity, is far from any residential estates, main roads or railways. Trees of the above species selected for tapping grew in close proximity from one another, which minimized environmental variability. All the sampled trees had a diameter larger than $25 \mathrm{~cm}$, which is consistent with published recommen- 


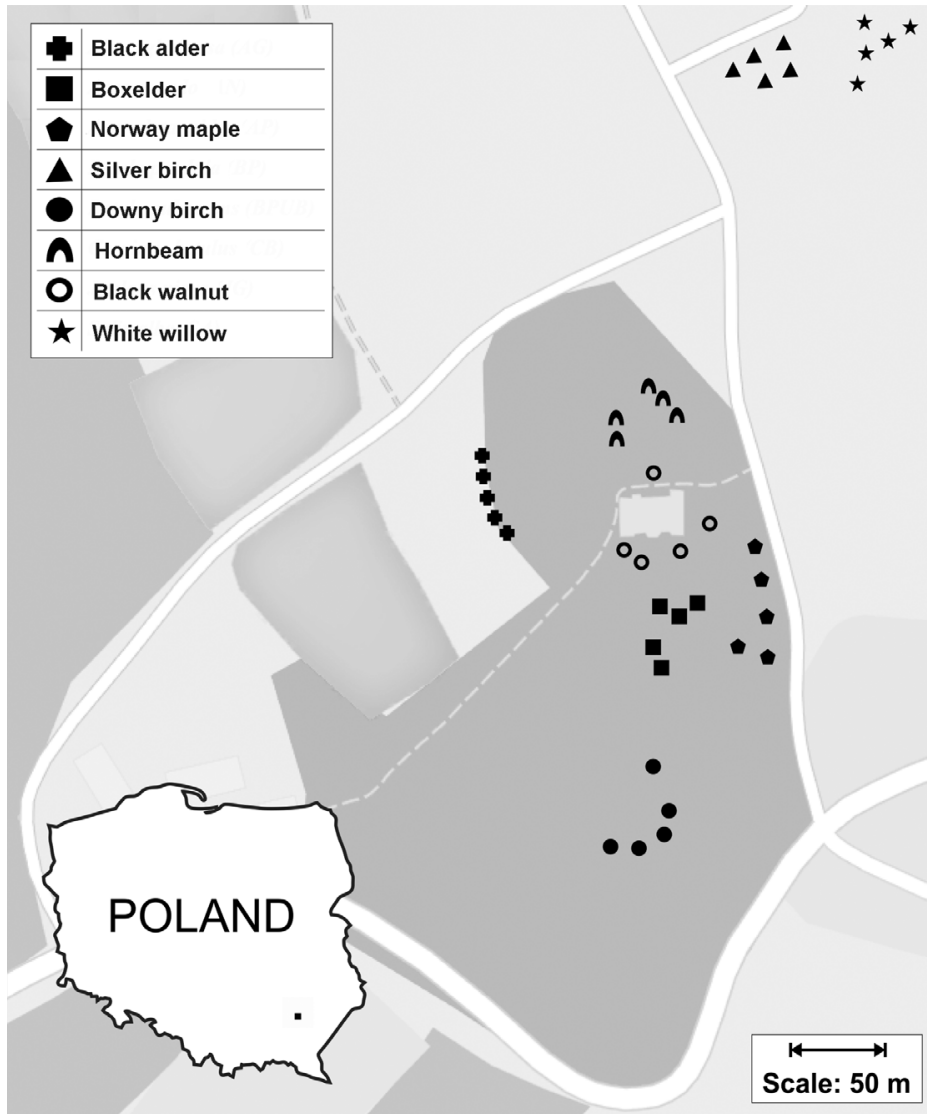

Fig. 1. Map showing the localisation of the tapped trees

dations (LAROCHELlE et al. 1998). The age of the trees was estimated with a noninvasive method, based on their diameter measured at the height of $1.3 \mathrm{~m}$ (PoŁucha, Dzioba 2013) - Table 1.

We established a protocol for sample collection according to some previously published methods (Yoon et al. 1992). We focused on minimizing the risk of microbial contamination, detrimental for samples. Before sap collection, a fragment of bark was removed from a tree with a sterile chisel, additionally disinfected with Octenisept (Schülke\&Mayr, Norderstedt, Germany). Spots of tapping were selected on the south side of a trunk, $50 \mathrm{~cm}$ above the ground. Collecting spots were sterilized with 70\% ethanol (POCH, Gliwice, Poland) for $30 \mathrm{~s}$. Holes (10 mm diameter, 4-6 cm deep, 30 angle) were bored with a sterile, autoclaved drill and cleaned of wooden shavings with a sterile scalpel (Schreiber, Fridingen, Germany). Collection of sap started 5 min after the flow began, once the area surrounding a given hole has been sterilized with 96\% ethanol (POCH, Gliwice, Poland) and flamed. Saps were gathered 
Approximate age of trees, the source of studied tree sap

\begin{tabular}{|c|c|c|c|c|c|c|c|c|c|}
\hline \multirow{2}{*}{$\begin{array}{c}\text { Age of } \\
\text { the tree }\end{array}$} & No. & $\begin{array}{c}\text { White } \\
\text { willow }\end{array}$ & $\begin{array}{c}\text { Black } \\
\text { alder }\end{array}$ & Hornbeam & $\begin{array}{c}\text { Black } \\
\text { walnut }\end{array}$ & $\begin{array}{c}\text { Downy } \\
\text { birch }\end{array}$ & $\begin{array}{c}\text { Silver } \\
\text { birch }\end{array}$ & Boxelder & $\begin{array}{c}\text { Norway } \\
\text { maple }\end{array}$ \\
\cline { 2 - 10 } & 1 & 80 & 60 & 20 & 70 & 20 & 20 & 60 & 50 \\
\cline { 2 - 10 } & 2 & 50 & 40 & 30 & 60 & 30 & 20 & 50 & 30 \\
\cline { 2 - 10 } & 4 & 80 & 50 & 20 & 90 & 20 & 20 & 50 & 20 \\
\cline { 2 - 10 } & 5 & 120 & 70 & 30 & 90 & 30 & 30 & 40 & 20 \\
\hline
\end{tabular}

into $0.015 \mathrm{dm}^{-3}$ sterile and flamed test-tubes, which were again flamed before closing. Thed holes in the tree trunks were sealed with Koro-Derma pruning ointment (Bros, Poznań, Poland).

Sap samples were frozen $\left(-20^{\circ} \mathrm{C}\right)$ immediately after collection. A whole batch of frozen samples was transferred to the Malopolska Centre of Food Monitoring, where the samples were thawed and analyzed with atomic absorption spectroscopy.

Standard solutions were prepared from $1000 \mathrm{mg} \mathrm{dm}^{-3}$ stock solution (CertiPUR, Merck KGaA, Germany) of sodium, potassium, calcium, magnesium, zinc and copper by dilution with double deionised water (Milli-Q Millipore $18.2 \mathrm{M} \Omega \mathrm{cm}^{-1}$ resistivity). Nitric acid (65\%) Suprapur reagent was purchased from Merck KGaA (Germany). All the plastic and glassware were cleaned by soaking in dilute $\mathrm{HNO}_{3}(1: 9)$ and were rinsed with distilled water prior to use.

A Varian AA240FS (Varian, Mulgrave, Victoria, Australia) atomic absorption spectrometer equipped with single-element, hollow cathode lamps and an air/acetylene burner was used for determinations of the content of calcium, magnesium, sodium, potassium and zinc. The instrumental parameters were set according to the manufacturer's recommendations (Table 2). The determination of copper was performed using an atomic absorption spectrometer Varian AA240Z (Varian, Mulgrave, Victoria, Australia) with Zeeman correction equipped with a Varian GTA-120 electrothermal atomizer coupled with an automatic sample dispenser. Argon was used as inert gas. The determination of copper was done under the conditions specified in Table 2. A MARS Xpress microwave closed system (CEM, Matthews, North Carolina, USA) was used. About $2 \mathrm{~g}$ of each sample was digested in $0.010 \mathrm{dm}^{-3}$ of nitric acid (65\%, Suprapur, Merck KGaA, Germany) in a microwave digestion system and diluted to $0.025 \mathrm{dm}^{-3}$ with double deionised water. Blank digest was obtained in the same way. Instrumental parameters and settings were: $5 \mathrm{~min}$ for $600 \mathrm{~W}$ at $100^{\circ} \mathrm{C}, 5 \mathrm{~min}$ for $1200 \mathrm{~W}$ at $180^{\circ} \mathrm{C}, 15 \mathrm{~min}$ for $1200 \mathrm{~W}$ at $200^{\circ} \mathrm{C}$ and 5 min vent.

Determinations of the content of investigated components were carried out in duplicate, and average results were calculated as $\mathrm{mg}$ of element per $\mathrm{kg}$ of fresh matter. 
Table 2

Experimental parameters used in the atomic absorption spectrometry measurements

\begin{tabular}{|c|c|c|c|c|}
\hline \multicolumn{5}{|c|}{ Conditions for FAAS } \\
\hline Element & $\begin{array}{c}\text { acetylene } \\
\left(\mathrm{L} \min ^{-1}\right)\end{array}$ & 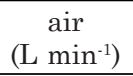 & $\begin{array}{c}\text { wavelength } \\
(\mathrm{nm})\end{array}$ & slit width $(\mathrm{nm})$ \\
\hline $\mathrm{Ca}$ & 2.0 & 13.5 & 427.7 & 0.5 \\
\hline $\mathrm{Mg}$ & 2.0 & 13.5 & 285.2 & 0.5 \\
\hline $\mathrm{Na}$ & 2.0 & 13.5 & 589.0 & 0.5 \\
\hline $\mathrm{K}$ & 2.0 & 13.5 & 766.5 & 0.5 \\
\hline $\mathrm{Zn}$ & 2.0 & 13.5 & 213.9 & 1.0 \\
\hline \multicolumn{5}{|c|}{ Conditions for GFAAS } \\
\hline Instrumental conditions & \multicolumn{4}{|c|}{$\mathrm{Cu}$} \\
\hline Argon flow $\left(\mathrm{mL} \min ^{-1}\right)$ & \multicolumn{4}{|c|}{300} \\
\hline Sample volume $(\mu \mathrm{L})$ & \multicolumn{4}{|c|}{20} \\
\hline Modifier $(\mu \mathrm{L})$ & \multicolumn{4}{|c|}{5} \\
\hline Wavelength (nm) & \multicolumn{4}{|c|}{327.4} \\
\hline \multicolumn{5}{|l|}{ Heating program: } \\
\hline Drying 1 & \multicolumn{4}{|c|}{95} \\
\hline Drying 2 & \multicolumn{4}{|c|}{120} \\
\hline Ashing & \multicolumn{4}{|c|}{900} \\
\hline Atomization & \multicolumn{4}{|c|}{2300} \\
\hline Cleaning & \multicolumn{4}{|c|}{2300} \\
\hline
\end{tabular}

Statistical analysis was performed as a one-way analysis of variance (one-way ANOVA), with a tree species being a differentiating factor. Statistica v. 10.0 sofwater was used. In order to find significantly different means, a post-hoc analysis with the Tukey's honest significance test was used. The differences were deamed statistically significant at the cutoff level $a=0.05$.

\section{RESULTS AND DISCUSSION}

We detected significant variability in concentrations of the elements between individual trees of all the analyzed species (Figure 2). However, no significant differences were confirmed in the concentrations of copper $(p=0.23)$ or calcium $(p=0.23)$ between the the tree species.

The distribution of particular elements in the eight tree species was found to be as follows. The highest average concentration of copper was detected in the sap from hornbeam $\left(1.26 \mathrm{mg} \mathrm{dm}^{-3}\right)$ and white willow $\left(1.02 \mathrm{mg} \mathrm{dm}^{-3}\right)$. The highest average concentration of calcium was found in the sap of white willow $\left(75 \mathrm{mg} \mathrm{dm}^{-3}\right)$ and black walnut $\left(65.24 \mathrm{mg} \mathrm{dm}^{-3}\right)$. Furthermore, the highest average concentration of zinc was detected in white willow sap (3.04 mg 

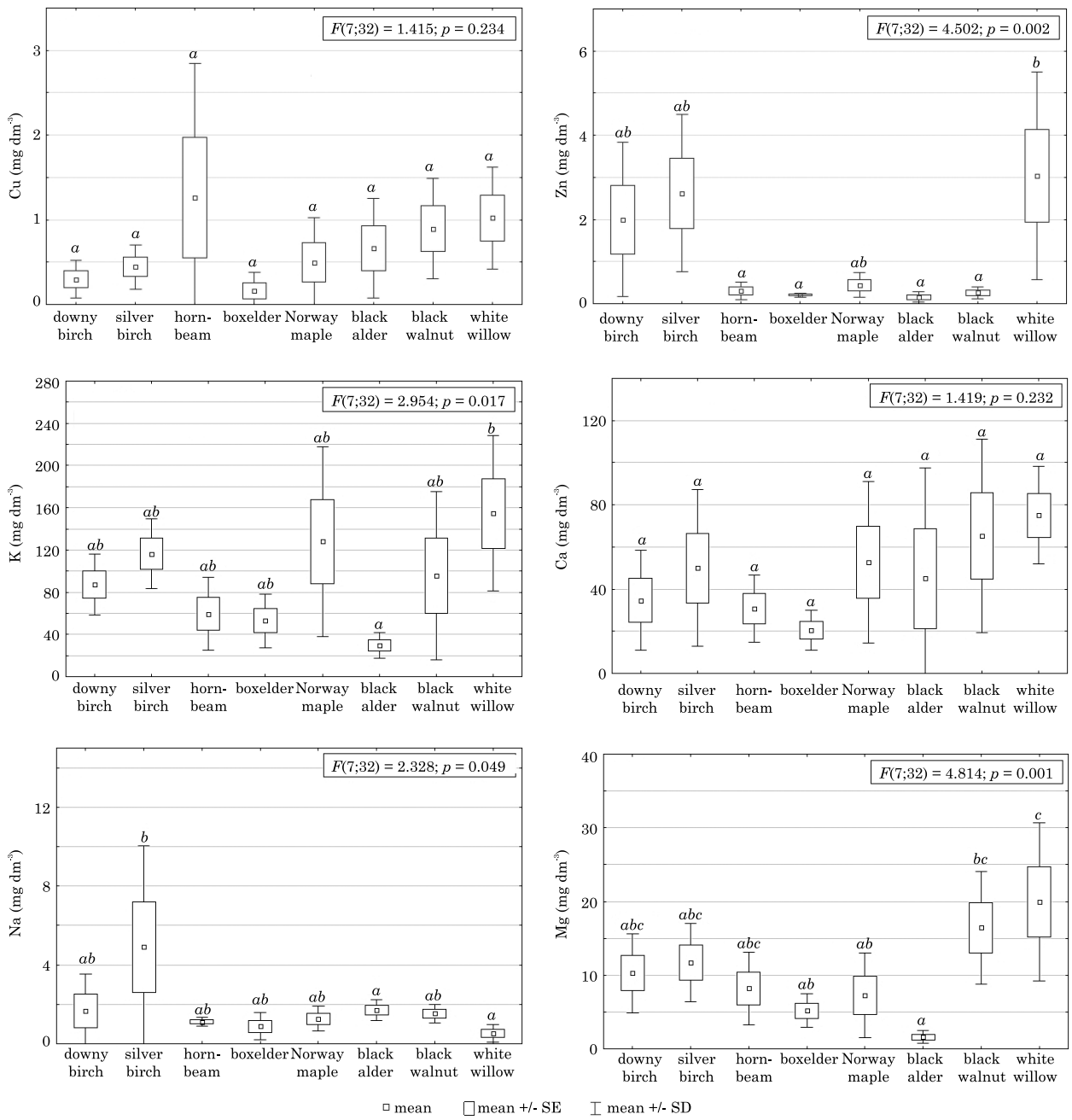

Fig. 2. Graphs show the mean content of metallic elements in sap collected from different tree species: $a, b, c$ - the same letters indicate a lack of statistically significant differences between the studied species $(p$-value $<0.05)$

$\left.\mathrm{dm}^{-3}\right)$ and silver birch sap $\left(2.62 \mathrm{mg} \mathrm{dm}^{-3}\right)$. The highest average concentration of potassium was detected in the sap of white willow $\left(154.53 \mathrm{mg} \mathrm{dm}^{-3}\right)$ and Norway maple $\left(128 \mathrm{mg} \mathrm{dm}^{-3}\right)$, while the highest average concentration of sodium was found in the samples taken from silver birch $\left(4.9 \mathrm{mg} \mathrm{dm}^{-3}\right)$ and black alder $\left(1.71 \mathrm{mg} \mathrm{dm}^{-3}\right)$. The highest average concentration of magnesium was measured in the sap of white willow $\left(19.98 \mathrm{mg} \mathrm{dm}^{-3}\right)$ and black walnut $\left(16.43 \mathrm{mg} \mathrm{dm}^{-3}\right)$.

In brief, the sap of white willow was characterized by the highest average concentration of magnesium, zinc, calcium and potassium. Noteworthy, 
the same sap was the one that contained the least sodium. On the other hand, the sap with the lowest average concentrations of the metallic elements (magnesium, zinc, potassium, copper and calcium) was tapped from black alder and boxelder (Figure 3).
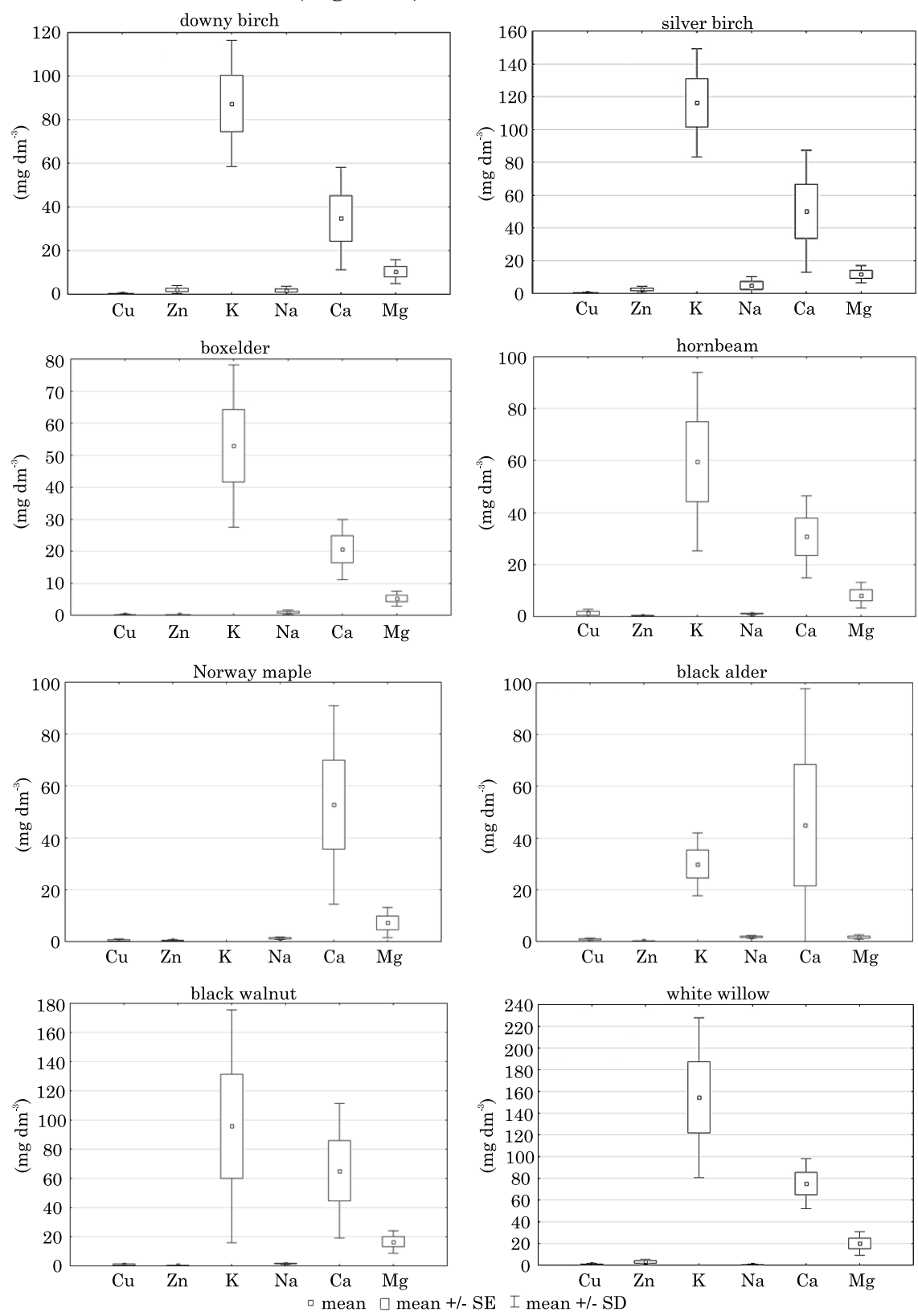

Fig. 3. Graphs show the mean content of different metallic elements in sap of all studied tree species 
When all the types of tree sap (40 samples) were pooled together, we did not detect any correlation between the age of trees and the content of metallic elements in their sap (Figure 4). However, the samples obtained from a

\begin{tabular}{|c|c|c|c|c|c|}
\hline $\mathrm{Zn}$ & $\mathrm{Na}$ & $\mathrm{Mg}$ & $\mathrm{K}$ & $\mathrm{Ca}$ & $\mathrm{Cu}$ \\
\hline 0.001 & 0.083 & 0.135 & 0.009 & 0.110 & 0.048 \\
\hline
\end{tabular}

Fig. 4. Coefficients of determination $\left(R^{2}\right)$ showing the lack of correlation between the age of the trees and the concentration of different elements for all species pooled together

single species underwent a similar analysis, a positive correlation between the tree age and the content of selected elements appeared. The concentration of copper in sap correlates with the age of white birch $\left(R^{2}=0.63\right)$ and black walnut $\left(R^{2}=0.6\right)$. The zinc concentration strongly correlates with the age of black walnut trees $\left(R^{2}=0.9\right)$. Moreover, analogous positive correlations were found for calcium in boxelder $\left(R^{2}=0.86\right)$ and Norway maple $\left(R^{2}=0.6\right)$, and magnesium in boxelder trees $\left(R^{2}=0.73\right)$. We did not find any correlation between the amount of sodium or potassium in sap and the age of any of the trees.

Our results are in agreement with measurements of other authors who used the same analytical method. For example, there is a visible resemblance in the composition of the silver birch sap between our samples and the ones collected in Lithuania (VIŠKELIS, RubinskienE 2011). Moreover, while comparing our observations with the published data, we noticed a similarity in the composition sap from trees belonging to the same genus. Namely, the downy birch sap we analyzed resembles the sap collected from Japanese white birch in South Korea (JEONG at al. 2012). Furthermore, the mineral content of the boxelder sap is similar to Korean and Manchurian maples (CHUNG et al. 1995).

Tree sap as part of a diet can be a valuable source of nutrients and minerals, especially in early spring season. In this study, we measured the concentrations of six different elements in sap. Four of them are classified as mineral elements and two as electrolytes, according to Polish nutrition standards (JAROsz 2012). We can conclude that all the studied types of tree sap are a valuable source of copper. Namely, consumption of one liter of sap from black walnut, white willow and hornbeam covers accordingly 100\%, 113\% and $140 \%$ of the copper recommended dietary allowance. On the other hand, the sap of downy birch, silver birch and white willow proved to be a rich source of zinc. Consumption of one liter of the above sap covers respectively $25 \%, 33 \%$ and $38 \%$ of the daily recommended intake of this element.

However, the tree sap we studied cannot be treated as a primary source of magnesium. The highest concentration of this element was found in sap of white willow, black walnut and silver birch. However, one liter of this sap covers between $3.7 \%$ to $6.3 \%$ of the daily recommended magnesium intake. 
Moreover, sap of the studied tree species cannot be considered a significant source of sodium, potassium or calcium (Figure 5).
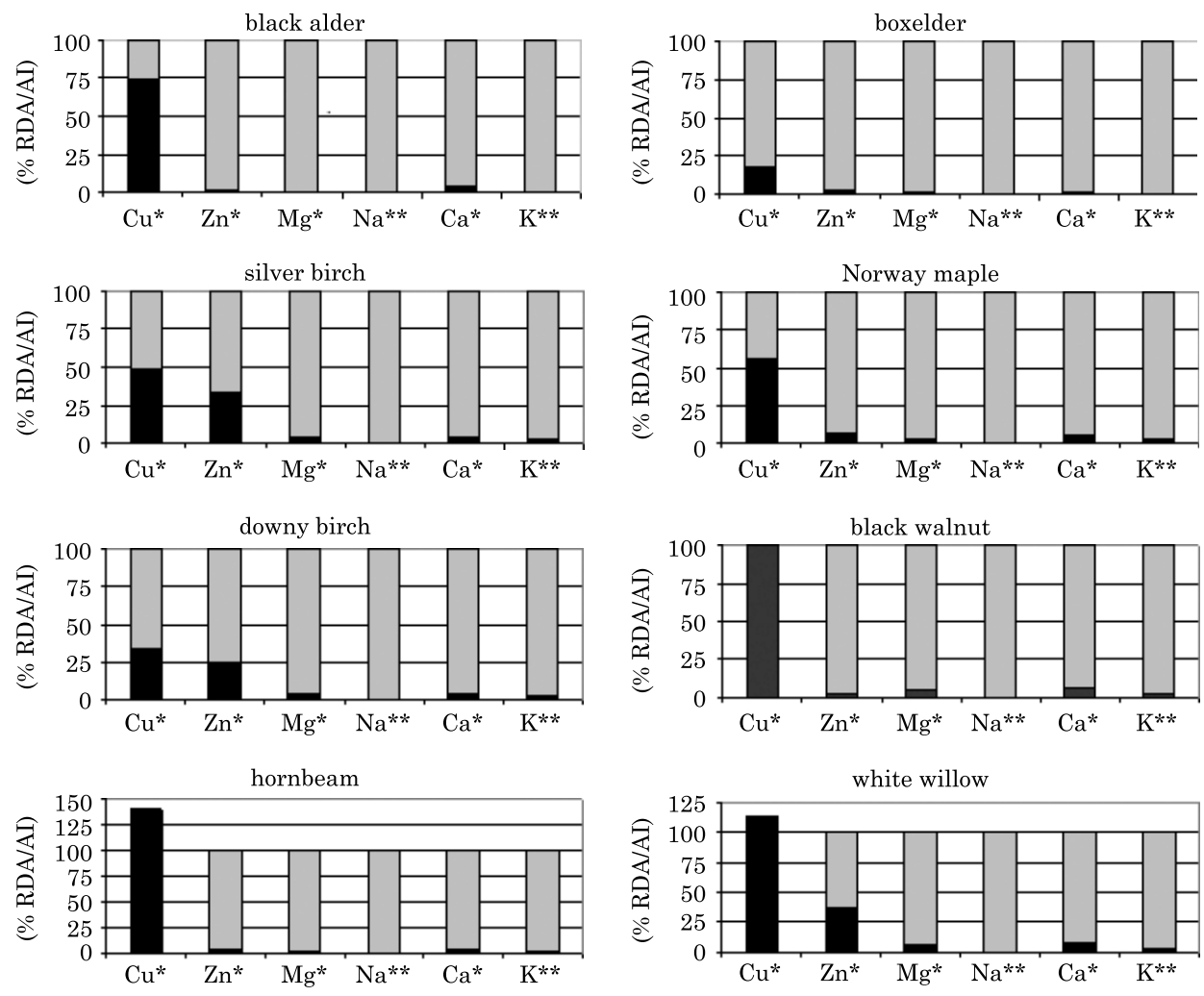

* RDA - Recommended Dietary Allowances, ** AI - Adequate Intake

Fig. 5. The graphs show a comparison between the mineral content of one liter of sap (mean value calculated for five individual trees within any given species) as a percentage of the recommended dietary allowances or adequate intake for an adult person

The question which tree species produce sap with thecomposition which is most beneficial for human health has been addressed in literature. Kūka and colleagues compared the content of calcium and potassium in sap of silver birch and Norway maple and concluded that as far as mineral content is concerned, the later one is a better choice (KüKA et al. 2013). Our study shows that among the investigated species, the sap of white willow contains the highest concentrations of mineral elements, namely magnesium, zinc, calcium and potassium (Figures 3 and 5). Interestingly, white willow is rarely used as a source of sap in Central and Eastern Europe. Ethnobotanical reports mention its use in the region of Siberia (SvANBERG et al. 2012).

We observed high intraspecies variability in the composition of collected sap. However, the samples analyzed in this study were collected from indivi- 
dual trees growing in close proximity to one another. Therefore, environmental factors (especially different types of soil or climate) can be excluded as a source of the observed variability. Differences in the composition of sap depending on the conditions in which trees were growing have been reported in literature. For example, Hajru and Hulden studied the amount of metallic elements in sap of silver birches growing at increasing distances from sulfide deposits. They observed that the concentration of these elements decreased as the distance from deposits increased (HAJRU, HuldÉn 1990). Moreover, Morselli detected significant differences in the concentration of sodium in sap collected from maple trees growing in the middle of a forest and at its edge, in close proximity to roads deiced with sodium chloride (MorsELLI, WHALEN 1987). Also, there are studies focusing on plant physiology which confirm the dependence between the composition of soil and the concentration of inorganic elements in sap of different tree species (SCHNEIDER et al. 1996, White, Broadley 2001, Tagliavini, Millard 2005). However, our study shows significant differences in the composition of sap collected from individual trees of the same species, which were growing in the same conditions. This emphasizes the role of inter-individual variability in the constitution of tree sap, which has to be taken into consideration in studies addressing the quality of tree sap or their use in environmental monitoring.

\section{CONCLUSIONS}

1. There is significant variability in the content of metallic elements both between and within the studied tree species.

2. The examined tree sap may be considered to be a valuable dietary supplement, as it is particularly rich in copper, zinc and magnesium.

3 . The highest content of minerals (magnesium, zinc, calcium and potassium) was detected in the sap of white willow.

4. The sap from silver birch trees, most popular in Poland and also commercially available as readymade soft drink, can be considered to be a significant source of magnesium and zinc.

\section{REFERENCES}

Chung M.-J, Kim Y.-S., Lee I.-S., Jo J.-S., Sung N.-J. 1995. The components of the sap from gorosoe (Acer mono Max.) and sugar maple (Pseudo-sieboldianum Kom.). J. Korean Soc. Food Sci. Nutr., 24(6): 911-916.

Greenough J.D., Fryer B.J., Mallory-Greenough L. 2010. Trace element geochemistry of Nova Scotia (Canada) maple syrup. Can. J. Earth Sci., 47(8): 1093-1110. DOI: 10.1139/E10-055

HarJu L., HuldÉn S.-G. 1990. Birch sap as a tool for biogeochemical prospecting. J Geochem. Explor., 37(3): 351-365.

Jarosz M. (ed.) 2012. Nutritional standards for the Polish population. Amendment. IŻŻ Warszawa. (in Polish) 
Jeong J.S. Lee C.H., Kim H.Y., Hwang I.G., Shin C.S., Park E.S., Lee J., Jeong H.-S. 2011. Characeteristic of Goroshoe (Acer mono Max.) sap with different collection times after ultra filtration. J. Korean Soc. Food Sci. Nutr., 40(5): 753-758. DOI: 10.3746/jkfn.2011.40.5.753

Jeong S.J., Lee C.H., Kim H.Y., Lee S.H., Hwang I.G., Shin C.S., Lee J., Jeong H.S. 2012. Quality characteristics of the white birch sap with varying collection periods. J. Korean Soc. Food Sci. Nutr., 41(1): 143-148, DOI: 10.3746/jkfn.2012.41.1.143

KŪKa M., ČAKSTE I., GeRŠEBEKA E. 2013. Determination of bioactive compounds and mineral substances in Latvian birch and maple saps. Proc. Latv. Acad. Sci. Sect. B Nat. Exact Appl. Sci., 67(4-5): 437-441.

Larochelle F., Forget E., Rainville A., Bousquet J. 1998. Sources of temporal variation in sap sugar content in a mature sugar maple (Acer saccharum) plantation. Forest Ecol. Manag., 106: 307-313.

Morselli M.F., Whalen M.L., BaggetT K.L. 1985. Characteristics of maple syrup processed from bleach-treated sap. J. Food Prot., 48: 204-206.

Morselui M.F., Whalen M.L. 1987. „Salty” syrup from roadside sugar maples in decline. Maple Syrup Dig., 27(4): 23-24. https://www.uvm.edu/ uvmaple/saltysyrup1987.pdf

Moon H.-S., Kwon S.-D., Park S.-B., Goo J.-W. 2004. Sap collection and major components of Acer mono in Mt. Jiri. Korean J. Ecol., 27(5): 263-267. DOI: 10.5141/JEFB.2004.27.5.263

Papp N., Czégényi D., Hegedús A., Morschhauser T., Quave C. L., Cianfaglione K., Pieroni A. 2014. The uses of Betula pendula Roth among Hungarian Csángós and Székelys in Transylvania, Romania. Acta Soc. Bot. Pol., 83(2): 113-122. DOI: 10.5586/asbp.2014.011

PoŁucha I., Dzioba K. 2013. A proposal of valorization of green areas around the educational institutions. Teka Kom. Arch. Urb. Stud. Krajobr., 9(3): 45-55. (in Polish)

Schneider S., Gesler A., Weber P., von Sengbusch D., Hanemann U., Rennenberg H. 1996. Soluble $N$ compounds in trees exposed to high loads of $N$ : a comparison of spruce (Picea abies) and beech (Fagus syhatica) grown under field conditions. New Phytol., 134(1): 103-114.

Svanberg I., Sõukand R., Łuczaj Ł., Kalle R., Zyryanova O., Dénes A., Papp N., Nedelcheva A., Š́škauskattė D., Ko€odziejska-Degórska I., Kolosova V. 2012. Uses of tree saps in northern and eastern parts of Europe. Acta Soc. Bot. Pol., 81(4): 343-357. DOI: 10.5586/asbp.2012.036

Tagliavini M., Millard P. 2005. Fluxes of nitrogen within deciduous fruit trees. Acta Sci. Pol. Hort. Cult., 4(1): 21-30.

Viškelis P., Rubinskienè M. 2011. The chemical composition of birch sap. Sodininkystè ir Daržininkystè, 30(3-4): 75-81. (in Lithuanian)

White J.P., Broadley M.R. 2001. Chloride in soils and its uptake and movement within the plant: A review. Ann. Botan., 88(6): 967-988. DOI: 10.1006/anbo.2001.1540

Yoon S.L., Jo J.S., Kiм T.O. 1992. Utilization and tapping of the sap from birches and maples. Mokchae Konghak., 20(4): 15-20.

Zyryanova O.A., Terazawa M., Koike T., Zyryanov V.I. 2010. White birch trees as resource species of Russia: Their distribution, ecophysiological features, multiple utilizations. Euroasian J. For. Res., 13(1): 25-40. 